Centre for Evidence Based Medicine, Nuffield Department of Primary Care Health Sciences, University of Oxford, Oxford

jeffrey.aronson@phc.ox.ac.uk Cite this as: BMJ 2021;375:n3059 http://dx.doi.org/10.1136/bmj.n3059 Published: 10 December 2021

\section{When I use a word .... The Precautionary Principle: a brief history}

Two ideas precede the modern Precautionary Principle. First, that prevention is better than cure, exemplified by an aphorism in an early 13th century book of Jewish aphorisms, the Sefer Hasidim: "Who is a skilled physician? He who can prevent sickness." Secondly, Thomas Sydenham's 17th century assertion that in healthcare it is important above all not to do harm, "primum est ut non nocere." These two ideas come together in the Vorsorgeprinzip, which was incorporated into German legislation for maintaining clean air in the 1960s and 1970s, and first appeared in English-language documents in 1982, which referred to taking a precautionary approach or precautionary measures, or more formally as the Precautionary Principle. The principle features in international documents such as the Rio Declaration and in many pieces of EU legislation relating to topics as diverse as genetically modified organisms, food safety, the safety of toys, and invasion of alien species of animals, plants, fungi, or microorganisms.

Jeffrey K Aronson,

\section{Proverbial precaution}

Authors who write about the Precautionary Principle often begin with observations on the old proverb "prevention is better than cure." The proverb in its modern form, or something like it, first appeared in English in the 17th century, but evidence of the idea can be found in many ancient Chinese texts, dating as far back as Huang Ti, the Yellow Emperor (2697-2597 BC). "The skilful doctor treats those who are well, while the less skilful treats those who are ill” is a saying attributed to Ch'in Yueh-jen (ca. 225 BC). Henry de Bracton in De Legibus et Consuetudinibus Angliae (ca. 1240) wrote "cum melius et utilius sit in tempore occurrere quam post causam vulneratam quaerrere remedium" ("It is better and more advantageous to deal with something in good time, than to pursue a remedy after the harm has been done"). And a similar sentiment appeared in an early 13th century book of Jewish aphorisms, the Sefer Hasidim (the Book of the Pious): "Who is a skilled physician? He who can prevent sickness.”

However, direct comparison of the proverb with the Precautionary Principle is fallacious, for two reasons. First, the proverb, in medical contexts, primarily refers to preventing diseases or disorders, not other types of unwanted outcomes, such as harms from interventions. Secondly, prevention is absolute, and precautions do not always result in prevention. For example, the chance of an unwanted pregnancy can be reduced by “taking precautions," i.e.

implementing some form of contraception, but such precautions do not guarantee prevention; even the most effective form of contraception does not rule out the possibility of a pregnancy.

\section{Primum est ut non nocere}

A saying that is more closely equivalent to the Precautionary Principle, "Primum est ut non nocere," was reportedly coined by Thomas Sydenham, ${ }^{1}$ as cited in Thomas Inman's book Foundation for a New Theory and Practice of Medicine (1860), ${ }^{2}$ which incidentally was dedicated to George Henry Lewes, George Eliot's lover:
"We believe that the principle of doing evil to the constitution that good may come, is as false in medicine as it is in theology.

"We believe that this vicious principle has been adopted, unintentionally, ever since our science has been studied, and that medicine will never rest on a firm basis so long as this doctrine retains its hold on the minds of practitioners. Lest it should be objected that our opinions are new-fangled, and therefore unworthy of credence, we crouch under the cloak of Sydenham, and say, that our motto is none other than a translation of his Latin aphorism respecting a physician's duties, viz.: -

"Primum est ut non nocere."

This is often quoted as "primum non nocere," following its use in that form by Lewis A Stimson in an 1879 paper in the American Journal of Medical Science ${ }^{3}$ : "The maxim that our first duty is to do no harm-primum non nocere-is not intended to reduce us to the rank of simple spectators; it is to stimulate us to attain greater accuracy in diagnosis, greater skill in treatment, and quicker perception of indications." Concerns that still preoccupy us.

The maxim is usually translated as "first do no harm." However, "primum" in Latin means not only "first" but, among other things, as a noun "the principal point," "the chief thing," and as an adjective "best above all." Thus, the saying might be better rendered as "It is important above all not to do harm." This principle is also reflected in the last of the four pillars of modern medical ethics-autonomy, justice, beneficence, and non-maleficence.

Of course, the idea that doctors should do no harm to their patients goes back much further, at least to

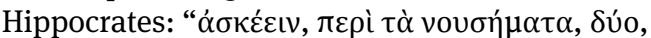

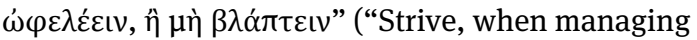
diseases, for two outcomes: to do good or at least to do no harm"). Not quite "primum est ut non nocere," but the same idea.

However, even this precept is inadequate, since it does not take into account the fact that, even when there are potential harms, from which no 
interventions are free, the chance of benefit may outweigh the chance of harm, the latter being a chance that may be worth taking. A more careful examination of the Precautionary Principle is warranted.

\section{Modern origins of the Precautionary Principle}

The German idea of the Vorsorgeprinzip, which combined the ideas of prevention and avoidance of harm, is the forerunner of the modern Precautionary Principle. The German proverb "Vorsorge ist besser als Nachsorge" (literally "foresight is better than hindsight") is equivalent to "prevention is better than cure." However, the word "Vorsorge" has also come to mean "precaution," blurring the distinction between the two.

The idea has been traced back to the late 19th century, but the principle started to make its mark in 1964 in a document titled Technische Anleitung zur Reinhaltung der Luft (Technical Instructions for Maintaining Clean Air, often referred to as TA Luft), which was later incorporated into the 1974 Bundes-Immissionsschutzgesetz, the Federal Pollution Control Act, which permitted only emissions that were unavoidable. The 1972 London Convention on the Prevention of Marine Pollution by Dumping of Wastes and Other Matter also incorporated the principle, although without naming it as such, instead referring to "a precautionary approach," ${ }^{4}$ a phrase that has had currency elsewhere.

The principle was formally endorsed internationally in 1982, when the World Charter for Nature was adopted by the United Nations General Assembly and it entered English in the same year, in a paper on the control of air pollution in West Germany. ${ }^{5}$ It was first implemented internationally in 1987 through the Montreal Protocol. ${ }^{6}$ It has since been incorporated into many aspects of EU law. For example, the EU's regulatory framework for chemicals (Regulation (EC) No $1907 / E C$, known as REACH) 7 is based on the precautionary principle. Some legally binding international treaties, such as the Rio Declaration, ${ }^{8}$ also incorporate it. And a search for "precautionary principle" in the legislation.gov.uk website yields 112 hits.

The areas in which the Precautionary Principle applies have been defined in Title XX Environment, Article 191 of the Treaty on the Functioning of the European Union (the Lisbon Treaty, 2007)9 ${ }^{9}$ :

preserving, protecting and improving the quality of the environment;

protecting human health;

prudent and rational use of natural resources;

promoting measures at international level to deal with regional or worldwide environmental problems, and in particular combating climate change.

Although human health is mentioned, it is not clearly stated how far the treaty intended it to extend beyond protecting it from the effects of the environment.

In future articles I shall discuss the definition of the Precautionary Principle and give examples. Meanwhile, here is text from the EU's Regulation (EC) No 178/2002, under the heading "Precautionary principle" ${ }^{10}$ :

"In specific circumstances where, following an assessment of available information, the possibility of harmful effects on health is identified but scientific uncertainty persists, provisional risk management measures necessary to ensure the high level of health protection chosen in the Community may be adopted, pending further scientific information for a more comprehensive risk assessment."
Competing interest: None declared.

Smith CM. Origin and uses of primum non nocere--above all, do no harm!/ Clin Pharmacol 2005;45:371-7. doi: 10.1177/0091270004273680 pmid: 15778417

2 Inman T. Foundation for a New Theory and Practice of Medicine. John Churchill, New Burlington Street, 1860: 244.

3 Stimson LA. On abdominal drainage of adherent portions of ovarian cysts as a substitute for completed ovariotomy. Am J Med Sci

1879;78:88-101doi: 10.1097/00000441-187907000-00006.

4 International Maritime Organization. Convention on the Prevention of Marine Pollution by Dumping of Wastes and Other Matter. 1972. https://www.imo.org/en/OurWork/Environment/LCLP/Documents/LC1972.pdf.

5 Currie DP. Air pollution control in West Germany. Univ Chic Law Rev 1982;49:355-93doi: 10.2307/1599426.

6 UN Environment Programme. Ozone Secretariat. The Montreal Protocol on Substances That Deplete the Ozone Layer. Annex VI. 19 November 2004. https://ozone.unep.org/treaties/montrealprotocol.

7 Regulation (EC) No. 1907/2006 of the European Parliament and of the Council of 18 December 2006. https://www.legislation.gov.uk/eur/2006/1907/contents\#.

8 Convention on Biological Diversity. Rio Declaration on Environment and Development. https://www.cbd.int/doc/ref/rio-declaration.shtml.

9 The Lisbon Treaty (2007). Title XX. Environment. Article 191. https://assets.publishing.service.gov.uk/government/uploads/system/uploads/attachment_data/file/228848/7310.pdf.

10 Regulation (EC) No 178/2002 of the European Parliament and of the Council of 28 January 2002. Chapter II, Section 1, Article 7. Precautionary principle. 